\title{
The Influence of Multimedia Assisted Inquiry Learning Methods on My Heroes' Theme of Critical Thinking Skills and Learning Outcomes of Class IV Students of Elementary School
}

\author{
Yulis Purwanita1, ${ }^{1 *}$, Yatim Riyanto ${ }^{1, b}$, and Totok Suyanto ${ }^{1, c}$ \\ ${ }^{1}$ Postgraduate of Basic Education, Surabaya State University, East Java, 60213, Indonesia \\ JI.Rektorat Unesa, Lidah Wetan Kecamatan Lakarsantri Surabaya, East Java, 60213, Indonesia \\ a yulis.17070855103@mhs.unesa.ac.id; b jatimriyanto@gmail.com; c totoksuyanto@unesa.ac.id \\ *Corresponding Author \\ Whatsapp Number [081216193994]
}

How to Cite: Purwanita, Y., Riyanto, Y., \& Suyanto, T (2019). The Influence of Multimedia Assisted Inquiry Learning Methods on My Heroes' Theme of Critical Thinking Skills and Learning Outcomes of Class IV Students of Elementary School. International Journal for Educational and Vocational Studies, 1 (2), 75-81. DOI: https://doi.org/10.29103/ijevs.v1i2.1435

\section{ARTICLE HISTORY}

Received: 7 May 2019

Revised: 25 May2019

Accepted: 28 May 2019

KEYWORDS

Multimedia

Inquiry Learning Method

Heroes' Theme

Critical Thinking Skills

Learning Outcomes

\section{ABSTRACT}

This study aims to analyze and observe the effect of inquiry learning methods on critical thinking skills and learning outcomes in Grade IV Elementary Schools. This research was conducted at Sekolah Dasar Negeri Percobaan 2 Malang (State Elementary School Experiment 2 Malang), in the first semester of 2017-2018 school year. This study uses two classes namely the experimental class and the control class. The research sample was class IV B students as the experimental class and IVC class as the control class. The research instruments used were observation sheets of critical thinking skills and learning outcomes tests. Data analysis techniques used include normality test, homogeneous test, and independent test t-test. The results showed: Multimedia-assisted Inquiry learning methods had an effect on critical thinking skills and learning outcomes of fourth grade students of State Elementary School Experiment 2 Malang. Thus, the media is used as an alternative medium in social studies learning in the fourth grade.

\section{INTRODUCTION}

Education "is" part "of the" needs "of living" humans. "The existence of" education "can" increase "the ability to" think "with" good "and "Acquire" knowledge. According to Hadi (2008: 20) the highest proportion in formal education is a lesson. Teaching is a process of transferring knowledge, attitudes, likes and behaviors to students through teaching assisted by various learning resources. The teaching can be given through 3 education channels, namely formal, informal, non-formal. "Formal" education (school) "has" the main problem "in" teaching "that is" decreasing the ability of students to receive lessons. "This is evidenced from" acquisition "Results of" daily "tests, namely" partially "'" students have not "fulfilled the minimum" completeness "criteria (KKM)," so that "must" be held "remedial / improved" value "to" meet the "value" of the KKM. There are several things that can be influenced by the high or low value of learning or student achievement. Such things usually come from outside, such as strategies or ways of teaching teachers, methods used, media used, and learning environments. While internal factors can be intelligence, motivation, self discipline, and various things that come from students.

The success of a learning can be seen from the achievement of learning objectives as evidenced by changes in student learning outcomes obtained. So that related to the use of methods, approaches and strategies that have a large influence on the achievement of student learning outcomes. According to Piaget, Inquiry has an educational concept that emphasizes "preparing students to conduct experiments on their own extensively so that they see what is happening, want to do something, ask questions, and find answers themselves, and connect findings to one another, comparing what he found with what other students found. Therefore we need a learning method that accommodates this, one of which is the Inquiry Learning Method. The researcher concludes the theory from the theory above that Inquiry is a learning method that prepares students in situations to conduct their own experiments so that they can think critically to find and find answers to a problem in question. According to Marzano, one of the main goals of 
attending school is to improve the ability of students to think critically, so that they can make rational decisions about what to do or what to believe. These critical thinking skills need to be trained early on in students. This is because critical thinking is needed in every profession and it allows one to face reality in a reasonable and independent way.

According to Supardi (2011:182) social studies education emphasizes the skills students must have in solving problems, both problems that exist within the scope of themselves to even complex problems. In essence, social studies education is more focused on providing provision of problem solving skills faced by students. Learning activities using the Inquiry learning method will be suitable if combined with learning media, the intended learning media is a medium that can be used as a tool to support the success of learning that can improve student learning enthusiasm. "The media used in this study were educational videos about heroes. By using multimedia to support social studies learning through the Inquiry learning method so that pleasant experiences can be obtained to meet each other's needs and can present something that can be seen and heard to be able to motivate students in learning and provide learning experiences to students. Multimedia has a very good role and benefits in terms of applications that provide a variety of the best services including videos that can be downloaded first, then stored and can be used even though they don't have a network that is online.

According to Vaughan (2004: p1), Multimedia is a combination of text, images, sounds, animations and videos sent to you via a computer or other electronic device or by digital manipulation. The following is a study that was conducted by I Kd. Arik Antini, I Gst. Agung Oka Negara, I Wy. The 2014 Sudjana entitled "Guided Inquiry Learning Method Assisted by Audio-Visual Media Influences Social Studies in Class V Elementary School Students Group Letda Kajeng." The results showed that there were significant differences in social studies between groups of students who learned using media-assisted inquiry learning methods. audio-visual with those taught using conventional learning. This is evident from the difference in average Social Sciences between the experimental group and the control group namely $=74.45>=57.74$. The results of the analysis using the t-test were obtained $t_{\text {count }}=5.58>$ $t_{\text {table }}=2.00$. It can be concluded that the guided inquiry learning method assisted by audio-visual media has an effect on the social studies of students in grade $\mathrm{V}$ in the Elementary School of Letda Kajeng Academic Year 2013/2014.

Other studies that "support" the "solving" of the "problem" are "research" that are "carried out" by "Leni Sofiannida, Sri Utaminingsih, Su'ad" 2018 "with" title " Effects of Guided Inquiry Learning Methods Based on Local Wisdom Against Skills "Critical Thinking My Heroes' Class IV Elementary School." "The results of this show that: 1) guided inquiry methods based on effective local wisdom to improve critical thinking skills in the theme of my elementary school fourth grade hero are somewhat of a guided inquiry method. This is evidenced by the results of the average guided inquiry method based on local wisdom and not on the inquiry method initiative (76.55 > 67.94), 2) there is a significant effect of students critical thinking skills between guided inquiry methods based on local wisdom and guided Inqiry method. This is evidenced by the results of $t_{\text {count }}>t_{\text {table }}(2.757>2.002)$ and a smaller significance value with a significance level of $5 \%(p=0.010$ $>0.05)$.

\section{METHODS}

Type of research is Quasi Experimental is a design that has a control group but is not fully functional to examine external variables such as student motivation, student interest, and learning time that can affect the implementation of experiments. This method is used to determine whether or not there is an influence between the use of Inquiry and Multimedia learning methods that are used on critical thinking skills and student learning outcomes.

\subsection{Research design}

The design of this study is design non equivalent (pre-test and post-test) design Control Group. In this design the experimental group and the control group were subjected to pre-test and post-test, but only the experimental group received treatment $\mathrm{X}$. In the experimental class the implementation of learning uses thelearning method Inquiry. While the learning control class is conventional with the lecture method. Then the final test is carried out to find out the social science about the cognitive abilities of students who have attended learning.

\subsection{Research Samples}

The research sample used Cluster Random Sampling. This technique takes samples randomly from groups. Random sampling is done to determine the experimental class and the control class. Based on the results of randomization, it was obtained class IV-B as experiment and class IV-C as control. The experimental sample uses the Multimedia Assisted Inquiry Learning Methods while the control class uses conventional learning methods, namely the lecture method.

\subsection{Data Analysis}

From the results of assessment of students' critical thinking skills can be calculated using the formula listed below:

$$
\mathrm{M}=\frac{\sum F}{N} x 100
$$

Source: Indarti (2008: p.25)

Analysis of data from student learning outcomes, can be calculated using a formula listed below: 


$$
\begin{aligned}
\text { Score }= & \frac{\mathbf{B}}{\mathbf{N}} \times \begin{array}{l}
\mathbf{1 0 0} \% \\
\text { Source: } \text { Yamin (2010: p. 159) }
\end{array}
\end{aligned}
$$

Based on the information on minimum completeness criteria (KKM) in State Elementary School Experiment 2 Malang, students are declared to have completed their learning outcomes if they get a value of $\geq 70$.

\section{RESULTS AND DISCUSSIONS}

The use of media tailored to the learning material and can draw enthusiasm of students in the learning process. The media used can be seen in the following figure:
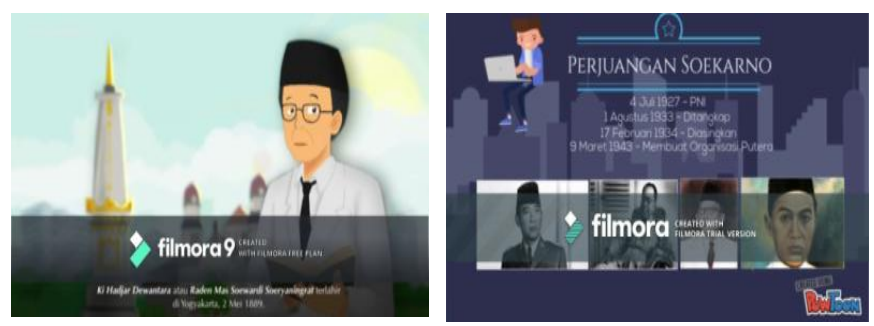

Figure 1. Multimedia (Video)

Table 1. Results of the Normality Test

\begin{tabular}{ccccc}
\hline Variables & Class & Significance & Level & Information \\
\hline Critical Thinking & Control &, 125 & 0,05 & Normal \\
\hline Critical Thinking & $\begin{array}{c}\text { Experim } \\
\text { ents }\end{array}$ &, 177 & 0,05 & Normal \\
\hline $\begin{array}{c}\text { Learning Results } \\
\text { (Pretest) }\end{array}$ & Control &, 120 & 0,05 & Normal \\
\cline { 1 - 1 } \cline { 5 - 5 } $\begin{array}{c}\text { Learning Results } \\
\text { (Posttest) }\end{array}$ &, 119 & 0,05 & Normal \\
\hline $\begin{array}{c}\text { Learning Results } \\
\text { (Pretest) }\end{array}$ & Experim &, 128 & 0,05 & Normal \\
\cline { 1 - 1 } $\begin{array}{c}\text { Learning Results } \\
\text { (Posttest) }\end{array}$ & ents &, 181 & 0,05 & Normal \\
\hline
\end{tabular}

Test for normality using the chi square test formula with a significance level of 0.05 or $5 \%$. If the significance of $<0.05$, the conclusion is that the data is not normal. But if the significance is $>0.05$, the data is normally distributed. Variables of control critical thinking obtained a significant value of $0.125>0.05$. The experimental critical thinking variable obtained a significant value of $0.177>0.05$. The variables of the pretest learning outcomes of the control class students obtained a significance value of $0.120>0.05$ on the posttest learning outcomes of the control class students obtained a significance value of $0.119>0.05$. Variables of pre-student learning outcomes in the experimental class obtained a significance value of $0.128>$ 0.05 , on the posttest learning outcomes of students in the experimental class obtained a significance value of $0.181>$ 0.05 . So that it can be stated that all variables in table 4.18 are normally distributed. The homogeneity test was carried out using the Oneway Anova test with the help of SPSS 21 program. The homogeneity test results are shown in the table 2 .
Table 2. Results of the Homogenities

\begin{tabular}{c|c|c|c|c}
\hline \multicolumn{5}{c}{ Test of Homogeneity of Variances } \\
\hline & $\begin{array}{c}\text { Levene } \\
\text { Statistic }\end{array}$ & df1 & df2 & Sig. \\
\hline Thinking Critical &, 255 & 1 & 48 &, 616 \\
\hline Pretest &, 490 & 1 & 48 &, 487 \\
\hline Post test & 1,604 & 1 & 48 &, 211 \\
\hline
\end{tabular}

Table 2 is homogeneity test data using a significance level of 0.05 or $5 \%$. If the significance is $<0.05$, the data group variant is not homogeneous, and if the significance is $>0.05$, the data group variant is homogeneous. The critical thinking skills variable obtained a significance value of $0.616>0.05$, it is said that the variable is homogeneous, the learning outcome variable (pretest) obtained a significance value of $0.487>0.05$, it can be said that the variable is homogeneous. Whereas the learning outcome variable (posttest) obtained a significance value of $0.211>0.05$, it can be said that the variable is homogeneous. From these two variables it can be concluded that the data is homogeneous or has met the basic assumptions of homogeneity. After the normality and homogeneity tests are carried out, the hypothesis testing can be used to determine the effect of Multimedia assisted Inquiry learning methods on critical thinking skills and Social Sciences learning outcomes of my heroic theme for fourth grade students of State Elementary School Experiment 2 Malang,. The decision making can also be seen in a significant level $\mathrm{p}$ Sig. (2-tailed). If $\mathrm{p}>0.05, \mathrm{H} 0$ is accepted and $\mathrm{H}_{\mathrm{a}}$ is rejected, if $\mathrm{p}<0.05$ then $\mathrm{H}_{0}$ is rejected and $\mathrm{H}_{\mathrm{a}}$ is accepted (Triton, 2006, p.175). The following are the results of the t-test of critical thinking skills and student learning outcomes in the experimental group using the Inquiry learning method and the control group using conventional models.

Table 3. Results of the T-Test

Group Statistics

\begin{tabular}{cccccc}
\hline & Class & N & Mean & Std. Deviation & $\begin{array}{c}\text { Std. Error } \\
\text { Mean }\end{array}$ \\
\hline \multirow{2}{*}{ Thinking Critical } & Control & 25 & 84,84 & 10,323 & 2,065 \\
\cline { 2 - 6 } & experiment & 25 & 61,12 & 10,787 & 2,157 \\
\hline \multirow{2}{*}{ Pre-test } & Control & 25 & 64,60 & 11,173 & 2,235 \\
\cline { 2 - 6 } & experiment & 25 & 63,00 & 11,547 & 2,309 \\
\hline \multirow{2}{*}{ Post-test } & Control & 25 & 88,00 & 9,242 & 1,848 \\
\cline { 2 - 6 } & experiment & 25 & 73,80 & 10,924 & 2,185 \\
\hline
\end{tabular}

In the results of the analysis with the Independent Sample T-test showed that critical thinking skills obtained a tcount of 7.944, a value of ttable at (df.48) and a real level of 0.05 of 1,677 , if a comparison was made then tcount $<t_{\text {table }}$ with the results of sig. 2 tailed at 0,000 $<0,05$ and said to accept Ho which means that there is a significant difference. Which means there are differences in critical thinking skills and student learning outcomes between the control class and the experimental class. At the pretest the tcount is 0.498 . The value of ttable at (df.48) and the real level of 0.05 is 1,677 , if a comparison is made then $t_{\text {count }}<$ 
$\mathrm{t}$ table with the results of sig. 2 tailed $0.621>0.05$ and said to accept $H_{0}$ which means that there is no significant difference. Which means there is no difference in student learning outcomes between the control class and the experimental class at the time of the pretest. Whereas in the Post-test, the tcount is 4.962 . The value of ttable is at (df.48) and the real level of 0.05 is 1,677 , if a comparison is made then $t_{\text {count }}>t_{\text {table }}$ with the results of sig. 2 tailed at $0,000<0,05$ and said to receive $\mathrm{H}_{\mathrm{a}}$ which means that there are significant differences. Which means that there are differences in student learning outcomes between the control class and the experimental class at the post-test.

\subsection{Effect of Multimedia Assisted Inquiry Learning Methods on Critical Thinking Skills}

Chapter will discuss the results of the research that focused on the findings so that the findings can be justified by theoretical studies. In table 3.9 the normality test for critical thinking skills is in the control class 0,125 and in the experimental class 0.177 . The two test groups have a significant value $>0,05$. It is concluded that the results of critical thinking skills in each are normally distributed. In table 3.10 the homogeneity test obtained the value of homogeneity of critical thinking skills in the control class of 0.487 and in the experimental class of 0.211 . With a significance number $>0.05$, it can be concluded that the sample variants are homogeneous or the same.

The average value of critical thinking students before treatment. Can be seen the acquisition of the average value of control is 1.829 while in the experimental class is 2.121 . Then by looking at the results of the Independent Samples Test, the T-test obtained a tcount of 7.944, a value of ttable at (df.48) and a real level of 0.05 of 1,677, if a comparison was made then $t_{\text {count }}<t_{\text {table }}$ with the results of sig. 2 tailed at $0,000<0,05$ and said to accept Ho which means that there is a significant difference. Which means there are differences in critical thinking skills and student learning outcomes between the control class and the experimental class. The influence of the Inquiry learning method on critical thinking skills of students in the experimental class is in line with the opinion of Huda (2013: p. 318) that the Inquiry learning method is a learning model that is an alternative in solving problems that invite students to think creatively and critically. The problem given by the teacher to students and students is given confidence in solving problems will train and encourage mental students more critical.

Based on the discussion above, it can be concluded that the critical thinking skills of students who use the Inquiry learning method with class groups that use conventional learning models using the 2013 curriculum. This is supported by Dawsen's description in Wicaksono (2014, p. 85-92) which states "students who have good development of metacognition will be better able to solve problems, make decisions and think critically, are more motivated to learn, more able to regulate emotions and better able to overcome difficulties".
Based on the results of the elaboration of the above research related to the Inquiry learning method, there is the influence of critical thinking skills of students experiencing significant changes between classes using the Inquiry learning model compared to classes that only use conventional learning models. This finding is also supported by research relating to Inquiry learning methods conducted by Sadam Husein, Lovy Herayanti and Gunawan in 2015 entitled "The Effect of Using Interactive Multimedia on Mastery of Concepts and Critical Thinking Skills of Students on Temperature and Heat Material" that Inquiry learning method is very affect the mastery of students 'concepts in the temperature and heat material of class X SMA Negeri 1 and can be used or used as a learning model to improve students' critical thinking skills. The equation in this study is that both have the independent variable namely Inquiry learning method while in the use of media both use multimedia both previous research and in this study and the measured benchmarks are students' critical thinking skills and learning outcomes. Both of these studies showed good results and had an influence on the experimental class.

Furthermore, other studies that are in line with this research are research conducted by Hidayati Suhada in 2017 with the title "Inquiry Learning Method and Critical Thinking Ability to the Science Process Skills of Class V Students in Science Subjects". In this study, it has been proven that Inquiry learning methods can improve the thinking skills of fifth grade students of elementary school. The equation in this study is in the independent variables used, namely the Inquiry learning method and the students' critical thinking skills that are measured, similar to this study, the Y2 variable is learning outcomes. Both of these studies showed good results and had an influence on the experimental class and were successful.

\subsection{Effect of Multimedia Assisted Inquiry Learning Methods on Student Learning Outcomes}

Based on table 3.9 the results of the normality test for student learning outcomes on the pretest problem, namely the control class of 0.120 while in the experimental class is 0.128. Furthermore, for the results of the analysis of the normality of learning outcomes in the post test questions, namely in the control class of 0.119 while the experimental class is 0.181 . The two test groups have a significance value of $>0.05$, so it can be concluded that the data on student learning outcomes in each class are normally distributed. In table 3.10 the homogeneity test results obtained the value of student learning outcomes on the news question of 0,487 while in the experimental class of 0,211 . Both of these results have a significance value $>0.05$ can be concluded that the sample variants in the study were homogeneous or the same. The average value of students before the treatment (pretest) obtained an average value of control of 1.575 while in the experimental class amounted to 1 . 620 . Then by looking at the results of the Independent Sample T-test obtained a $t_{\text {count }}$ of 0.498 . The value of $t_{\text {table }}$ at (df.48) and the real level of 0.05 is 1,677 , if a comparison is 
made then $t_{\text {count }}<t_{\text {table }}$ with the results of sig. 2 tailed 0.621 $>0.05$ and said to accept $\mathrm{H}_{\mathrm{o}}$ which means that there is no significant difference. Which means there is no difference in student learning outcomes between the control class and the experimental class at the time of the pretest. After the learning treatment of the two classes, namely the experimental class and the control class, the next step was posttest. The results of the analysis of student learning outcomes during the implementation of the post test in the control class get an average value of 1,845 while in the experimental class is 2,200 . Then after seeing the results of the Independent Sample T-test, tcount was 4.962. The value of ttable is at (df.48) and the real level of 0.05 is 1,677 , if a comparison is made then $t_{\text {count }}>t_{\text {table }}$ with the results of sig. 2 tailed at $0,000<0,05$ and said to receive $H_{a}$ which means that there are significant differences. Which means that there are differences in student learning outcomes between the control class and the experimental class at the posttest.

At the time of the implementation of the news from both classes there was no significant difference. However, during the post test there were significant differences between the control class and the experimental class. This means that student learning outcomes using multimedia-assisted Inquiry learning methods are higher than the learning outcomes of students who use conventional models. The influence of the Inquiry learning method on student learning outcomes is in line with the opinions expressed by Nasution (Supardi, 2015: p.2) which says that learning outcomes are changes that occur in students, not only visible from their knowledge but visible changes in attitudes, skills , habits, understanding, and appreciation in someone who learns. From the description and the corroborating opinion above, it can be concluded that the Inquiry learning method has a significant effect related to student learning outcomes.

This finding is also supported by research conducted by Maria AF Mbari, Marianus Yufrinalis, and Theresia Nona in 2018 with the title "The Effect of Using Inquiry Learning Methods on Learning Outcomes and Student Motivation in Class V Elementary School Students". This research has similarities, namely learning outcomes, and this research together shows good results. This finding is also supported by research related to learning outcomes examined by Utami researchers Rukmaliani, Rosnita, and Mastar Asran with the title "The Influence of Inquiry Learning Methods on Science IV Learning Outcomes of Class IV Elementary School Students" indicating that this Learning Method is suitable for improving outcomes student learning. The dependent variable in this study is the same, namely measuring student learning outcomes. In this study, both showed the results of good and successful research.

\section{CONCLUSION}

This experimental research by applying multimedia-assisted inquiry methods can influence critical thinking skills and learning outcomes on the theme of my hero in grade IV elementary school. The media used fulfills good criteria after going through validation and field trials. This can be seen from the completeness of student learning outcomes in social studies subjects.

The value of normalized gain of critical thinking skills of the experimental class students is 0,177 and the control class is 0,125 . The normalized gain value of the prestest learning outcomes of the experimental class students is 0.128 and the control class is 0.120 . The normalized gain value of the posttest learning outcomes of the experimental class students is 0.181 and the control class is 0.119 . Test results of independent samples t-test of critical thinking skills showed that the value of tcount was 7.944, the value of ttable at (df.48) and the significance level of 0.05 was 1,677. the results of the test of independent samples t-test of the pretest learning results indicate that the tcount is 0.498. The value of ttable at (df.48) and the real level of 0.05 is 1,677 and the results of the test independent samples t-test of the posttest learning outcomes indicate that the value of $t_{\text {count }}$ is 4.962 . The value of table is at (df.48) and the significance level of 0.05 is 1,677 . so that it can be concluded that the multiedia-assisted Inquiry learning method has an effect on critical thinking skills and learning outcomes of fourth grade students of State Elementary School Experiment 2 Malang.

\section{REFERENCES}

Ahmad Susanto. (2014). Theory of Learning and Learning in Primary Schools, (Jakarta: Kencana Prenada Media Group)

Akdon, and Riduwan. (2013). Formulas and Data in Statistical Analysis. Bandung: Alfabeta

Akhmad Sudrajat. (2008). Definition of Approaches, Strategies, Methods, Techniques and Learning Models. Bandung: Sinar Baru Algensindo.

Arikunto, Suharsimi. (1996). Research Procedure A Practice Approach. Revised Edition. Jakarta: Rineka Cipta.

Arikunto, S. (2006). Research Management. Jakarta: Rineka Cipta.

Arikunto, S. (2013). Research Procedure: An Approach to Practice. Jakarta: Rineka Cipta.

Arikunto, Suhardjono, and Supardi. (2015). Classroom Education Research. Jakarta: Bumi Aksara.

Arsyad, A. (2002). Instructional Media. Jakarta: Raja Grafindo Persada

Arsyad. 2011. Learning Media. Jakarta: PT Raja Grafindo

Azhar Arsyad, MA. (2002). Learning Media. Jakarta: Rajawali Press

Azhar, Arsyad. (2009). Instructional Media . Jakarta: Raja Grafindo Persada Rineka Cipta.

Basri, Moh. Hasan. (2010). Learning theory. Surabaya: Surabaya State University

Benny A. Personal. (2017). Media \& Technology in Learning. Jakarta: PT. Balebat Prime Dedication.

Dahar, Ratna Wilis. (2006). Learning \& learning theories. Jakarta: PT. Gelora Aksara Pratama

Deviyanti, Faradiza Ainur. (2018). Comprehensive Papers: the effect of using the cooperative learning model of the type of snowball throwing with the help of flashcard media on the activities and results of social studies learning in fourth grade students of elementary school.

Effendi Sofian. (2012). Survey Research Method. Jakarta: LP3ES

Elsa Pratiwi. (2016). The Influence of Learning Method Inquiry on Learning Achievement of Class IV Students in the Subject Journal of Elementary 
School Teacher Education Edition 29 5th Year 2016. Faculty of Education Yogyakarta State University.

Hamalik, Oemar. (2009). Curriculum and Learning. Jakarta. Earth Literacy. Huda, Miftahul. (2013). Models of teaching and learning. Yogyakarta: Student Library

Hulfian, Then. (2010). Learning theories. Surabaya: Surabaya State University

I Kd. Arik Antini, I Gst. Agung Oka Negara, I Wy. Sujana. (2014). Guided Inquiry Learning Model Assisted by Audio-Visual Media Influence on Social Studies Learning Outcomes of Grade V Elementary School Students in the Class of Letda Kajeng. 2014 National Journal of Education. Department of Primary School Teacher Education, FIP of Education University of Ganesha Singaraja, Indonesia.

Iqbal Imanudin, Zainuddin, Syamsiati. (2015). The Effect of Using Audio Visual Media on Student Learning Outcomes in Learning in 2015 National Journal Class V. Study Program FKIP Elementary School Teacher Education Untan, Pontianak.

June1, Sethela., Yaacob2, Aizan. \& Khar Kheng1, Yeoh. (2014). Assessing the Use of Tertiary Students: An Action Research. Journal of education studies. ISSN 1913-9020 E-ISSN 1913-9039. Vol. 7, No. 8; 2014

Keengwe, J., G. Onchwari, \& Onchwari, J. (2009). Technology and Student Learning: Toward A Learner Centered Teaching Model. AACE Journal, 17 (2), 11-22. Retrieved from http: //www.editlib.0rg/f/26258

Kustandi, Cecep and Bambang Sutjipto. 2011. Learning Media; Manual and Digital. Bogor: Ghalia Indonesia.

Leni Sofiannida, Sri Utaminingsih, Su'ad. (2018). The Influence of Guided Inquiry Method Based on Local Wisdom Against Critical Thinking Ability of My Hero Theme Class IV Elementary School. Educational Scientific Journal in 2018. ISSN 2615-5443. Vol. 1 No. 2, August 2018 Page 83-90.

Lubis, Suryani. 2012. Relationship between the Use of Youtube Media andLearning

Maria AF Mbari'sOutcomes, Marianus Yufrinalis, Theresia Miss. (2018). The Effect of Using Inquiry Learning Methods on Student Learning Outcomes and Motivation. Journal of the Study of Mathematics and Learning and Science of IKIP Mataram

http://ojs.ikipmataram.ac.id/index.php/prismasains/index Bulan Tahun. Vol. , No, p-ISSN: 2338-4530 e-ISSN: 2540-7899 pp. 94-102

Munir. 2012. Multimedia Concepts \& Applications in Education. Bandung: Alphabet.

Naidu, Suwastika., Pandaram, Atishwar., Chand, Ashyineet fiji. (2017). Exploring the positive and negative impact of YouTube videos to enhance the student's undergraduate learning and Master's program. International Journal of Instructional Technology and Distance Learning. Australian 2017 ISSN 1550-6908. Volume 14 Number 8

Nani, Rosdijati. et al. (2010). Practice of Paikem IPS Elementary School. Jakarta: Erlangga

Nurman, Muhammad. (2008). Effect of Use of Inquiry and Expository Learning Methods on Political Attitudes of Democracy and Student Learning Achievement in PPKn Learning in High School (Experimental Study of the Effect of Learning Methods on Political Attitudes of Democracy and Learning Achievement of PPKn Students in NW Pancor High School-East Lombok) Singaraja State IKIP Postgraduate Program.

Riyanto, orphaned. (2007). Research Methodology Qualitative and quantitative education. Surabaya: Surabaya State University

Rusman, et al (2011) Information and Communication Technology Based Learning: Developing Teacher Professionalism. Jakarta: Rajawali Press. PT. Raja Grafindo Persada

Sadam Husein, Lovy Herayanti, Gunawan. (2015). Pengaruh Penggunaan Multimedia Interaktif Terhadap Penggunaan Konsep dan Keterampilan Berpikir Kritis Siswa Pada Materi Suhu dan Kalor. Jurnal Pendidikan Fisika dan Teknologi (ISSN. 2407-6902) Volume I No 3, Juli 2015.
Sadirman. (1996). Interaksi dan motivasi belajar-mengajar. Jakarta: PT Raja Grafindo Persada

Sani, Ridwan abdullah.,Manurung, Sondang R.,Suswanto, Hary.,Sudiran. 2017.Penelitian Pendidikan.Medan: Tira Smart Suryani, Nunuk., Setiawan, achmad.,Putria, Aditin.2018. Media Pembelajaran Inovatif dan Pembangannya. Bandung: PT. Remaja Rosdakarya Offset Bandung.

Siti Aisah, Kartono, Endang Uliyanti. (2014). Pengaruh Penggunaan Model Pembelajaran Inkuiri Terhadap Hasil Belajar Siswa Pada Pembelajaran IImu Pengetahuan Alam di Sekolah Dasar. Jurnsl Naisonal Tahun 2014. Program Studi Pendidikan Guru Sekolah Dasar FKIP Untan, Pontionak.

Sudjana, Nana dan Ahmad Rivai. (2002). Media Pengajaran. Bandung: Sinar Baru Algesindo.

Suhada, Hidayati (2017). Model Pembelajaran Inquiry dan Kemampuan Berpikir Kritis terhadap Keterampilan Proses Sains Siswa Kelas V Pada Mata Pelajaran IPA. JPD: Jurnal Pendidikan Dasar DOI: doi.org/10.21009/JPD.082.02 http://doi.org/10.21009/JPD

Sugiyono. (2014). Metode Penelitian Pendidikan Pendekatan Kuantitatif, Kualitatif Dan R\&D. Bandung: Alfabeta.

Supriatna, N. (2007). Pendidikan IPA di SD. Bandung: UPI PRESS.

Suyono. (2011). Teori dan konsep dasar: Belajar dan pembelajaran.Surabaya: PT. Remaja Rosda Karya

Utami Rukmaliani, Rosnita, Mastar Asran. (2017). Pengaruh Model Pembelajaran Inkuiri Terhadap Hasil Belajar IPA Siswa Kelas IV SD.jurnal Program Studi Pendidikan Guru Sekolah Dasar FKIP Untan Pontianak

Vinny Alfianti, Rosnita, Hery Kresnadi. (2015). Pengaruh Penggunaan Media Audio-visual Terhadap Hasil Belajar IPA Kelas V SD. Jurnal Nasional Tahun 2015. Program Studi Pendidikan Guru Sekolah Dasar FKIP UNTAN, Pontianak.

Yanti Bua. (2015). Pengaruh Penerapan Metode Pembelajaran Inquiry Terbimbing (Guided Inquiry) Terhadap Hasil Belajar Siswa di Sekolah Dasar. Jurnal Naisonal Tahun 2015. PGSD FIP Universitas Negeri Surabaya.

Yamin, Martinis. (2007). Profesionalisasi Guru \& Implementasi KTSP. Jakarta: Gaung Persada Press. 